Article

\title{
Ecotoxicological Effect of Aged Wood Leachates to Aquatic Organisms
}

\author{
Lyndon N. A. Sackey *, Klára A. Mocová and Vladimír Kočíi \\ Department of Environmental Chemistry, Faculty of Environmental Technology, University of Chemistry and \\ Technology, Technická 5, 16628 Praha 6-Dejvice, Prague, Czech Republic; klara.bajerova@vscht.cz (K.A.M.); \\ vlad.koci@vscht.cz (V.K.) \\ * Correspondence: sackeyl@vscht.cz
}

Received: 16 June 2020; Accepted: 20 July 2020; Published: 23 July 2020

\begin{abstract}
Wood is an important natural resource used for various human activities. Toxicity of wood leachate in aquatic organisms has been previously established, but whether storage over time has an impact on the quality of leachate has not been assessed. Hence, this research seeks to assess the toxicity of aged wood leachate in aquatic organisms. Five fresh wood samples were randomly selected from the Oboyow forest reserve in the eastern region of Ghana: Mahogany (Khaya ivorensis), Cedrela (Cedrela odorata), Emire (Terminalia ivorensis), Wawa (Triplochiton scleroxylon), and Ceiba (Ceiba pendandra) to assess their toxicity to aquatic organisms. Algal (Desmodesmus subspicatus) duckweed (Lemna minor) and daphnia (Daphnia magna) were carried out using exposures to concentrations of $20 \%, 30 \%$, $45 \%, 67 \%$, and $100 \% v / v$ of wood leachate with control media, because they represented various concentration rate levels of wood leachate toxicity in the test organisms. The toxicity of the various wood leachates might be due to high levels of biochemical oxygen demand (BOD), chemical oxygen demand (COD), and total organic carbon (TOC), i.e., metals and phenols. The $\% \mathrm{IC}_{50}$ of the various wood leachate ranged from $21.51-66.77 \%$ with mahogany exhibiting the highest toxicity and wawa the lowest. It was also observed that toxicity of wood leachates decreased as the wood leachate aged. The $\% \mathrm{IC}_{50}$ showed both confirmed and potential toxicity among the various wood leachates.
\end{abstract}

Keywords: aged wood leachate; toxicity; aquatic organisms; ecotoxicity; Ghana

\section{Introduction}

Wood has been used for centuries by humans as an essential material for daily activities and has been beneficial since the primitive state for its outstanding mechanical characteristics. Due to technological development, wood is widely used in various corners of human life. It is a natural product and storing such a natural product can be harmful to the environment. Wood contains organic compounds that are leached when put into contact with liquid such as resin acids, terpenes, fatty acids, and tannins [1]. A generated liquid called leachate contains compounds, which when released into water bodies, may cause adverse impact on aquatic organisms [2]. The storage of logs awaiting to be processed is remnant of post-processed woodchips and sawdust stored on impermeable surfaces. The water from rainfall, snowmelt, or irrigation in contact with them result in the generation of leachate. Leachate needs to be managed and usually pumped into a treatment pond or holding receptacle before being released into a water body.

In this study, we used aquatic organisms Lemna minor (duckweed), Desmodemus Subspicatus (algae,) and Daphnia magna (daphnia) because they play an important role in the maintenance of the ecosystem.

Desmodesmus subspicatus is a microscopic freshwater green alga that grows in the water column as free-floating plankton and can be found around the world, even in the soil [3]. Their color is a result of the green pigment chlorophyll, which is surrounded by a membrane and forms a conspicuous 
structure called a chloroplast [4]. It is a primary producer at the base of the food chain and it is an important source of food for zooplankton and/or fish [4]. D. subspicatus may be a useful bio-indicator of nutrient conditions in lakes and as a model organism for investigating physiological, ecological, and/or ecotoxicological analysis [5]. The effect of log-yard storm water runoff on D. subspicatus was tested and the result shows that the log-yard storm water had a negative effect on the test organism [6]. The variations in the toxicity of the two water cycles indicated that a total hydrological assessment of the treatment of the storm water from the log-yard had an effect on the environment. One of the test organisms was D. subspicatus and after the test it was observed that the Aspen wood leachate inhibited algal growth at a very low concentration.

Lemna minor (genus Lemna) is a small floating plant with a single root. It is indigenous in most of Africa, Asia, Europe, and North America [7]. It is usually found in freshwater ponds and slow-moving streams. The fronds are oval and light green, and only a few cells thick. Aerenchyma assists with floatation [8]. Duckweed can grow at temperatures between 6 and $33^{\circ} \mathrm{C}$, and optimal pH between 6.5-8.0 [7]. Many wastewater studies have been performed using L. minor as the test organism for determining toxicity. Duckweed has also proven its capability to be used as test organism for complex effluent bioassays and herbicide pollutants in aquatic environments [9]. L. minor was used as a sensitive endpoint to assess the toxicity of organic aquatic micropollutants based on the chlorophyll content. The result demonstrated different sensitivities in tested micropollutants; industrial chemicals and pesticides were the most toxic [10]. L. minor was used for the growth inhibition test in this research. Actively growing L. minor in a 7-day static renewal assay was used to assess various liquid samples for their effects on Lemna growth [11].

Daphnia magna is a micro crustacean that belongs to the family crustacean and the order Cladocera. They are planktonic and one of the many small aquatic crustaceans called water fleas because of the way they swim. D. magna are found mostly in lakes, ponds, streams, and rivers in most parts of the world. They play vital ecological functions within these habitats by changing phytoplankton and bacteria into animal proteins and form a major part of the food for numerous fish species who feed on them [12]. Daphnia generally endure poor water quality and their dissolved oxygen varies from almost zero to super saturation. Daphnia are sensitive to poor water environments; a number of research and industrial groups use daphnia to test water quality. D. magna was used to determine toxicity from 52 textiles and the results indicated that the chemicals were toxic to the D. magna and hence they could affect the environment when released into water bodies without treatment [13]. Ecotoxicity of leachates from wood materials treated with wood preservatives was determined using D. magna [14]. The test results showed that the tested leachates from the treated wood preservatives were all toxic to D. magna. Aspen wood toxicity for leachates in aquatic organisms has been found and in our study, D. magna was one of the organisms used. It was observed from the toxicity test that the aspen wood leachate was toxic to D. magna [15].

Even though the toxicity of wood leachate to aquatic organisms has been proven by many studies, this research seeks to find out if aging wood leachates have a toxic effect on aquatic organisms. This research was informed by research conducted on the effect of toxicity of aged landfill leachates to aquatic organisms [16]. This research could help in the management of leachates generated from wood processing industries and leachate treatment.

\section{Materials and Methods}

\subsection{Sample Preparation}

Wood logs obtained through a random selection of a forest reserve in an eastern region of Ghana were cut into pieces; volumes ranged from $1-3 \mathrm{~cm}^{3}$. The dry matter content of $100 \mathrm{~g}$ of wood samples was determined at $105 \pm 5{ }^{\circ} \mathrm{C}$ [17] using a Memmert hot air oven, model UNE 300 (Schwabach, Germany) [18]. The leachates were stored in a $2 \mathrm{~L}$ plain glass bottle container covered with perforated parafilm to prevent any particles from entering and to allow gas exchanges for 1 month, 3 months, 
and 6 months under laboratory conditions where temperature ranged between $24-25^{\circ} \mathrm{C}$. The samples were put in an open place to receive natural light. The $\mathrm{pH}$, conductivity, and dissolved oxygen of the leachates were determined using the Wissenschaftlich-Technische Werkstätten WTW Multiline P4, 2.2. The biochemical oxygen demand (BOD) was determined using the suppression of the nitrification method [19]. Atomic absorption spectrometry (AAS) (SensAA GBC Scientific Equipment Dual, Australia) was used to determine selected metals ( $\mathrm{Cd}, \mathrm{Mn}, \mathrm{Cr}, \mathrm{Fe}, \mathrm{Cu}, \mathrm{Pb}$, and $\mathrm{Zn}$ ) present in wood leachates [20]. The GBC 933 AAS elemental detection limits were $0.009 \mathrm{mg} / \mathrm{L}$ for cadmium, $0.025 \mathrm{mg} / \mathrm{L}$ for $\mathrm{Cu}, 0.06 \mathrm{mg} / \mathrm{L}$ for $\mathrm{Pb}, 0.008 \mathrm{mg} / \mathrm{L}$ for $\mathrm{Zn}, 0.002 \mathrm{mg} / \mathrm{L}$ for $\mathrm{Mn}, 0.003 \mathrm{mg} / \mathrm{L}$ for Cr, and $0.005 \mathrm{mg} / \mathrm{L} \mathrm{for} \mathrm{Fe.}$ The World Health Organization (WHO) limits were used because they apply to wastewater discharge limits. The chemical oxygen demand (COD) was determined using potassium dichromate, modified via the semi-automated colorimetric method [21]. Total organic carbon (TOC) was determined using the high-temperature combustion method [22]. The total phenols was determined by the colorimetric method using Folin Ciocalteu's phenol reagent with Gallic acid [23].

\subsection{Toxicity Test}

\subsubsection{Algal Toxicity Test}

Algal medium is the bold's basal medium (BBM) for algae (Desmodesmus subspicatus) cultivation. It was constituted from distilled water and then dissolved in salts with a $\mathrm{pH}$ of $6.6 \pm 0.2$, according to [24-26]. The BBM was sterilized by using pressure cooker for $20 \mathrm{~min}$ at $121^{\circ} \mathrm{C}$.

A stock culture of the algae (Desmodesmus subspicatus) was prepared from strain number BRINKMANN 1953/SAG 86.81 via a culture collection of autotrophic organisms (CCALA), Institute of Botany of the AS CR, Třeboň, Czech Republic. The algae stock culture was prepared in a flow chamber by adding $4 \mathrm{~mL}$ of stock algae concentrate to $150 \mathrm{~mL}$ of cultivation medium in flat bottom glass flasks. Incoming air was cleaned from algae. Free flying bacteria were in a round atmosphere bacterial filter and immediately afterwards fed into algal suspension. The stock culture was transferred into a thermostat with a light cycle $(16 / 8 \mathrm{~h})$ under stable fluorescent light and temperature $\left(22 \pm 2{ }^{\circ} \mathrm{C}\right.$; 6000-8000 lux) for $72 \mathrm{~h}$ under continual aeration.

The test was carried out in $25 \mathrm{~mL}$ Erlenmeyer flasks. A volume of $15 \mathrm{~mL}$ of samples and growth medium were prepared in three replicates of different concentrations of sample: $20,35,45,67$, and 100\% $v / v$ for the toxicity test. The experiment was carried under sterile conditions. Initial algal concentration $(80,000$ cells/mL) was estimated by counting cells in the Bürker chamber. The control medium and samples were incubated in a thermostat with a light cycle $(16 / 8 \mathrm{~h})$ for $72 \mathrm{~h}$ under stable fluorescent light (6000-8000 lux) and temperature $\left(22 \pm 2{ }^{\circ} \mathrm{C}\right)$. After the exposure period, the algae cells were counted in the Bürker chamber under a microscope to calculate the algae growth rate.

\subsubsection{Duckweed Toxicity Test}

The Steinberg nutrient solution for duckweed cultivation was constituted from distilled water and dissolved appropriate concentrations of given salts. The solution had a $\mathrm{pH}$ of $5.5 \pm 0.2$, according to ISO guideline $20,079[27,28]$. The nutrient medium was sterilized in a pressure cooker for $20 \mathrm{~min}$ at $121^{\circ} \mathrm{C}$.

Prior to the test, the duckweed were transferred from a solid agar into the Steinberg nutrient solution and cultivated under $24 \pm 2{ }^{\circ} \mathrm{C}$ and light cycle (16 h/8 h; light/dark; 5000-6000 lux) for $168 \mathrm{~h}$. The test was conducted in $150 \mathrm{~mL}$ beakers. A volume of $100 \mathrm{~mL}$ of samples and growth medium were prepared in three replicates of different concentrations: $20 \%, 35 \%, 45 \%, 67 \%$, and $100 \% v / v$ for the toxicity test. An initial frond number of 10 was transferred into each replicate; the beakers were covered with transparent film. The samples were incubated for $168 \mathrm{~h}$ under the same temperature and light conditions as the culture. The plants were photographed at the beginning ( 0 day), middle ( 3 days). and end of the exposures (7 days) for frond number and area estimation. After the 7-day exposures, chlorophyll content ( $\mathrm{a}$ and b) was extracted in $99.8 \%$ methanol ( $48 \mathrm{~h} ; 4{ }^{\circ} \mathrm{C}$, dark) and measured by 
spectrophotometry (Hach, DR/2400, Germany). The calculation of the total chlorophyll content (a and b) was made according to a previous study [29]. The area were calculated by image analysis [30].

\subsubsection{Daphnia Toxicity Test}

The daphnia acute mobility inhibition test was performed using juvenile individuals of Daphnia magna Straus aged up to $24 \mathrm{~h}$, originating from ephippia (Microbiotests Inc., Mariakerke (Gent), Belgium). The test design was based on a previous work [31,32]. Aerated ADaM medium ( $\mathrm{pH} 7.8 \pm 0.2 ; \mathrm{O}_{2} \geq 7.0 \mathrm{mg} / \mathrm{L}$ ) [33] was used as a control. To ensure a sufficient amount of dissolved oxygen (minimum 90\%), the ADaM medium was aerated for at least a day before the toxicity test. Before the toxicity test, ephippia were culture in ADaM medium for 3-4 days under $24 \pm 2{ }^{\circ} \mathrm{C}$ and $16 / 8 \mathrm{~h}$ light cycle for hatching of ephippia.

The test was conducted in $25 \mathrm{~mL}$ beakers. A volume of $20 \mathrm{~mL}$ of samples and growth medium were prepared in three replicates of different concentrations: $20 \%, 35 \%, 45 \%, 67 \%$, and $100 \% v / v$ for the toxicity test. This was made in three replicates for both the control and samples. In total, 5 juveniles were transferred into $25 \mathrm{~mL}$ beakers containing various concentrations of leachate samples by Pasteur pipette, covered with transparent parafilm, and incubated at $24 \pm 2{ }^{\circ} \mathrm{C}$ and a $16 \mathrm{~h} / 8 \mathrm{~h}$ light/dark cycle (2000-3000 lux). The mobility (viability) of the test organisms was observed after the $48 \mathrm{~h}$ exposure.

\subsubsection{Statistical Analysis}

The logit model was used to calculate the dose response curve and GraphPad prism ver. 5.01 [34] in fitting of dose-response curves for all toxicity tests to determine the percentage median inhibition concentration $\left(\% \mathrm{IC}_{50}\right)$.

\section{Results and Discussion}

\subsection{Physical and Chemical Characteristics}

The wood leachate understudy showed different wood leachate colors after agitated with distilled water in a bottle for $24 \mathrm{~h}$ : mahogany-brown; cedrela- light Pink; wawa-colourless; emire-yellowish; and ceiba-light brown [18]. Moreover, after storage for 1 month, 3 months. and 6 months, there were changes in the wood leachate colors as the leachates aged: mahogany-dark brown; cedrela-deep pink; wawa-light brown; emire- deep yellow and ceiba-brown. The different colors and changes in leachate colors with age can be explained by oxidation, extractive degradation of extractives (especially lignin and tannins), and an increase in $\mathrm{pH}$ of the wood leachate with time and UV exposure [35,36].

Generally, $\mathrm{pH}$ increased when wood leachates aged, i.e., with time, leachates became more alkaline and this could be due to release of more hydroxide ions in the solution because of oxidation. The $\mathrm{pH}$ values ranged between 4.8-8.9, with emire having the lowest $\mathrm{pH}$ value and ceiba having the highest $\mathrm{pH}$ value across the various aged leachates. Generally, high values of $\mathrm{pH}$ were measured between $24 \mathrm{~h}$ and 1 month for most leachate samples. This could be due to storage time between the two, which indicated that during that period less biochemical reactions occurred.

Every wood leachate sample at $24 \mathrm{~h}$ had a woody or lumber smell, and as they aged the odor became offensive. This might be due to chemical changes in organic substances or decomposition of organic matter.

The conductivity of the wood leachates increased as the leachates aged, which indicated that more dissolved ions were released when leachates aged. Conductivity ranged between 174-1035 $\mu \mathrm{S} / \mathrm{cm}$. The lowest conductivity was observed in mahogany and the highest in ceiba. High values of conductivity were measured mostly between $24 \mathrm{~h}$ and 1 month of wawa, emire, and ceiba wood leachates. This could be due to the high concentrations of ions in fresh wood leachate and the storage period between other wood samples [35]. Furthermore, dissociation of inorganic compounds within the leachate with time could contribute to the increase in ion concentration within the leachates. The difference in the ion concentration by these wood leachates might be due to their different chemical composition, 
because it has been reported by [36] that different wood species yield different leachate compositions, which corresponds to their chemical composition. All the leachates conductivity were above the acceptable range for discharge into freshwater, that indicates the possibility of changing the quality of water when discharged without treatment [37].

Heavy metals $(\mathrm{Cd}, \mathrm{Mn}, \mathrm{Cr}, \mathrm{Fe}, \mathrm{Cu}, \mathrm{Pb}$ and $\mathrm{Zn}$ ) were determined because they are commonly encountered in polluted water [38]. $\mathrm{Cd}, \mathrm{Mn}, \mathrm{Cr}, \mathrm{Fe}, \mathrm{Cu}, \mathrm{Pb}$, and $\mathrm{Zn}$ were detected in various wood leachates at different concentration levels ranging between $0.02-3.78 \mathrm{mg} / \mathrm{L}$. (Tables $1-5$ ). $\mathrm{Pb}$ and $\mathrm{Zn}$ were under detection level throughout the various wood leachate samples. Mn was detected in all wood leachate samples and was within the permissible limit. Mn is an essential element for plant growth and might be supported in duckweed growth throughout various wood leachates [39]. Zn was predicted in other research to be a contributors of toxicity. However, in wood leachates samples for this experiment, it was under the detection limit in all wood leachate samples [40]. Fe concentration in the wood leachates were below the permissible limit. This could be due to both biochemical reaction, which reduced the Fe concentration with time.

Table 1. Metals identified over 24 h, 1, 3, and 6 months in mahogany wood leachate. The permissible limit defined by the World Health Organization (WHO) [41]. The mean values \pm standard deviation $(\mathrm{n}=3)$ are shown.

\begin{tabular}{cccccc}
\hline \multirow{2}{*}{ Metals } & \multicolumn{5}{c}{ Metal Concentrations (mg/L) in Wood Leachate Sample } \\
\cline { 2 - 5 } & WHO $\mathbf{2 0 1 1}(\mathbf{m g} / \mathbf{L})$ & $\mathbf{2 4} \mathbf{~ h}$ & $\mathbf{1}$ Month & 3 Months & $\mathbf{6}$ Months \\
\hline $\mathrm{Cr}$ & 0.01 & $0.51 \pm 0.1$ & $0.42 \pm 1.3$ & $0.33 \pm 0.7$ & $0.25 \pm 0.5$ \\
$\mathrm{Fe}$ & 0.30 & $0.30 \pm 0.2$ & $0.10 \pm 0.2$ & $0.60 \pm 0.2$ & $0.40 \pm 0.2$ \\
$\mathrm{Zn}$ & 3.00 & $\mathrm{ND}$ & $\mathrm{ND}$ & $\mathrm{ND}$ & $\mathrm{ND}$ \\
$\mathrm{Cu}$ & 2.00 & $0.70 \pm 0.5$ & $0.60 \pm 0.3$ & $0.50 \pm 0.2$ & $0.40 \pm 0.3$ \\
$\mathrm{Cd}$ & 0.03 & $0.10 \pm 0.2$ & $0.06 \pm 0.2$ & $0.05 \pm 0.1$ & $0.04 \pm 0.1$ \\
$\mathrm{~Pb}$ & 0.01 & $\mathrm{ND}$ & $\mathrm{ND}$ & $\mathrm{ND}$ & $\mathrm{ND}$ \\
$\mathrm{Mn}$ & 0.50 & $0.09 \pm 0.21$ & $0.07 \pm 0.11$ & $0.04 \pm 0.11$ & $0.02 \pm 0.22$ \\
\hline
\end{tabular}

ND: Not detected.

Table 2. Metals identified over 24 h, 1, 3, and 6 months in the emire wood leachate. The permissible limit defined by WHO [41]. The mean values \pm standard deviation $(n=3)$ are shown.

\begin{tabular}{cccccc}
\hline \multirow{2}{*}{ Metals } & \multicolumn{5}{c}{ Wood Sample Concentrations (mg/L) } \\
\cline { 2 - 6 } & WHO $\mathbf{2 0 1 1} \mathbf{( m g / L )}$ & $\mathbf{2 4} \mathbf{h}$ & $\mathbf{1}$ Month & 3 Months & $\mathbf{6}$ Months \\
\hline $\mathrm{Cr}$ & 0.01 & $0.48 \pm 0.11$ & $0.42 \pm 0.70$ & $0.34 \pm 2.1$ & $0.22 \pm 1.2$ \\
$\mathrm{Fe}$ & 0.30 & $0.20 \pm 0.12$ & $0.16 \pm 0.21$ & $0.14 \pm 0.1$ & $0.10 \pm 0.1$ \\
$\mathrm{Zn}$ & 3.00 & $\mathrm{ND}$ & $\mathrm{ND}$ & $\mathrm{ND}$ & $\mathrm{ND}$ \\
$\mathrm{Cu}$ & 2.00 & $0.68 \pm 0.23$ & $0.45 \pm 0.32$ & $0.19 \pm 0.11$ & $0.13 \pm 0.21$ \\
$\mathrm{Cd}$ & 0.03 & $0.10 \pm 0.12$ & $0.08 \pm 0.21$ & $0.06 \pm 0.14$ & $0.04 \pm 0.15$ \\
$\mathrm{~Pb}$ & 0.01 & $\mathrm{ND}$ & $\mathrm{ND}$ & $\mathrm{ND}$ & $\mathrm{ND}$ \\
$\mathrm{Mn}$ & 0.50 & $0.17 \pm 0.23$ & $0.25 \pm 0.31$ & $0.27 \pm 0.11$ & $0.34 \pm 0.22$ \\
\hline
\end{tabular}

$\mathrm{Cu}$ concentration levels in all wood samples were below the discharge limit and thus its effect on aquatic organisms might not be lethal. This could have supported the growth and development of aquatic organisms. Cd was above the permissible level [42] in all wood leachate samples by 2 times the reference value's $(0.03 \mathrm{mg} / \mathrm{L})$ discharge limit.

This could affect the chlorophyll levels in the fronds. It has been reported that $\mathrm{Cd}$ induces inhibition of photosynthetic systems and causes oxidative stress [43]. Cr was above the permissible limit over 37 times the discharge limit for wastewater and this could affect plant growth and development [44,45]. It was generally observed that metal concentration decreased as wood leachate aged and this could be 
due to metal degradation by microorganisms [45]. High levels of metals have a inhibitory effect on aquatic organisms development [46].

Table 3. Metals identified over $24 \mathrm{~h}, 1,3$, and 6 months in the cedrela wood leachate. The permissible limit defined by WHO [30]. The mean values \pm standard deviation $(n=3)$ are shown.

\begin{tabular}{cccccc}
\hline \multirow{2}{*}{ Metals } & \multicolumn{5}{c}{ Metal Concentrations (mg/L) in Wood Leachate Sample } \\
\cline { 2 - 6 } & WHO 2011 (mg/L) & $\mathbf{2 4} \mathbf{~ h}$ & $\mathbf{1}$ Month & 3 Months & 6 Months \\
\hline $\mathrm{Cr}$ & 0.01 & $0.24 \pm 0.10$ & $0.21 \pm 0.03$ & $0.18 \pm 0.20$ & $0.15 \pm 0.51$ \\
$\mathrm{Fe}$ & 0.30 & $0.10 \pm 0.12$ & $0.07 \pm 0.02$ & $0.05 \pm 0.02$ & $0.04 \pm 0.11$ \\
$\mathrm{Zn}$ & 3.00 & $\mathrm{ND}$ & $\mathrm{ND}$ & $\mathrm{ND}$ & $\mathrm{ND}$ \\
$\mathrm{Cu}$ & 2.00 & $0.12 \pm 0.21$ & $0.09 \pm 0.30$ & $0.06 \pm 0.30$ & $0.04 \pm 0.24$ \\
$\mathrm{Cd}$ & 0.03 & $0.04 \pm 0.12$ & $0.03 \pm 0.10$ & $0.01 \pm 0.20$ & $0.01 \pm 0.32$ \\
$\mathrm{~Pb}$ & 0.01 & $\mathrm{ND}$ & $\mathrm{ND}$ & $\mathrm{ND}$ & ND \\
$\mathrm{Mn}$ & 0.50 & $0.20 \pm 0.20$ & $0.15 \pm 0.30$ & $0.12 \pm 0.10$ & $0.10 \pm 0.31$ \\
\hline
\end{tabular}

ND: Not detected.

Table 4. Metals identified over $24 \mathrm{~h}, 1,3$, and 6 months in the wawa wood leachate. The permissible limit defined by $\mathrm{WHO}[30]$. The mean values \pm standard deviation $(n=3)$ are shown.

\begin{tabular}{cccccc}
\hline \multirow{2}{*}{ Metals } & \multicolumn{5}{c}{ Metal Concentrations (mg/L) in Wood Leachate Sample } \\
\cline { 2 - 6 } & WHO $\mathbf{2 0 1 1} \mathbf{( m g / L )}$ & $\mathbf{2 4} \mathbf{~ h}$ & $\mathbf{1}$ Month & 3 Months & 6 Months \\
\hline $\mathrm{Cr}$ & 0.01 & $0.34 \pm 0.2$ & $0.31 \pm 0.1$ & $0.26 \pm 0.11$ & $0.21 \pm 0.2$ \\
$\mathrm{Fe}$ & 0.30 & $0.41 \pm 0.2$ & $0.35 \pm 0.2$ & $0.28 \pm 0.3$ & $0.19 \pm 0.1$ \\
$\mathrm{Zn}$ & 3.00 & $\mathrm{ND}$ & $\mathrm{ND}$ & $\mathrm{ND}$ & $\mathrm{ND}$ \\
$\mathrm{Cu}$ & 2.00 & $0.73 \pm 0.4$ & $0.54 \pm 0.1$ & $0.38 \pm 0.2$ & $0.23 \pm 0.1$ \\
$\mathrm{Cd}$ & 0.03 & $0.09 \pm 0.1$ & $0.06 \pm 0.1$ & $0.04 \pm 0.1$ & $0.02 \pm 0.2$ \\
$\mathrm{~Pb}$ & 0.01 & $\mathrm{ND}$ & $\mathrm{ND}$ & $\mathrm{ND}$ & $\mathrm{ND}$ \\
$\mathrm{Mn}$ & 0.50 & $0.34 \pm 0.2$ & $0.31 \pm 0.1$ & $0.28 \pm 0.2$ & $0.20 \pm 0.3$ \\
\hline
\end{tabular}

ND: Not detected.

Table 5. Metals identified over 24 h, 1, 3, and 6 months in the ceiba wood leachate. The permissible limit defined by WHO [30]. The mean values \pm standard deviation $(n=3)$ are shown.

\begin{tabular}{cccccc}
\hline \multirow{2}{*}{ Metals } & \multicolumn{5}{c}{ Metal Concentrations $(\mathbf{m g} / \mathbf{L})$ in Wood Leachate Sample } \\
\cline { 2 - 5 } & WHO $\mathbf{2 0 1 1}(\mathbf{m g} / \mathbf{L})$ & $\mathbf{2 4} \mathbf{~ h}$ & $\mathbf{1}$ Month & 3 Months & 6 Months \\
\hline $\mathrm{Cr}$ & 0.01 & $0.38 \pm 0.2$ & $0.32 \pm 0.2$ & $0.27 \pm 0.1$ & $0.14 \pm 02$ \\
$\mathrm{Fe}$ & 0.30 & $0.36 \pm 0.2$ & $0.11 \pm 0.2$ & $0.08 \pm 0.3$ & $0.04 \pm 0.1$ \\
$\mathrm{Zn}$ & 3.00 & $\mathrm{ND}$ & $\mathrm{ND}$ & $\mathrm{ND}$ & $\mathrm{ND}$ \\
$\mathrm{Cu}$ & 2.00 & $0.25 \pm 0.1$ & $0.35 \pm 0.2$ & $0.41 \pm 0.1$ & $0.52 \pm 0.2$ \\
$\mathrm{Cd}$ & 0.03 & $0.19 \pm 0.3$ & $0.12 \pm 0.1$ & $0.07 \pm 0.2$ & $0.04 \pm 0.2$ \\
$\mathrm{~Pb}$ & 0.01 & $\mathrm{ND}$ & $\mathrm{ND}$ & $\mathrm{ND}$ & $\mathrm{ND}$ \\
$\mathrm{Mn}$ & 0.50 & $0.41 \pm 0.3$ & $0.36 \pm 0.2$ & $0.22 \pm 0.1$ & $0.15 \pm 0.2$ \\
\hline
\end{tabular}

ND: Not detected.

Generally, the BOD, COD, and TOC decrease as wood leachates age, indicating that with time organic leachate content biodegrades. Mahogany had the highest concentrations of BOD, COD, and TOC, while wawa had the lowest among the age of various wood leachates analyzed. This could be due to the presence of organic compounds (e.g., lignins, tannins, cellulose). The BOD and COD for the wood leachate samples were above the effluent discharge permissible limit of $40 \mathrm{mg} / \mathrm{L}$ and $120 \mathrm{mg} / \mathrm{L}$, respectively, except for wawa [47]. This indicated that there are more organic and inorganic compounds in the samples and hence will affect the quality of water and could also kill aquatic organisms when discharged without treatment. This will occur because organic matter in leachates through decomposition compete with aquatic organisms for available oxygen, hence reducing the 
quantity of oxygen available within the aquatic system, which might result in death. The BOD ranged between 9-268 mg/L (Table 6), which was more than 8 times the permissible limit.

Table 6. Biochemical oxygen demand (BOD), chemical oxygen demand (COD), and total organic carbon (TOC) of $24 \mathrm{~h}, 1,3$, and 6 months preparation and storage period of various wood leachates. The mean values \pm standard deviation $(n=3)$ are shown.

\begin{tabular}{|c|c|c|c|c|c|c|}
\hline \multirow{3}{*}{ Types of Wood } & \multicolumn{6}{|c|}{ Leachate Age } \\
\hline & \multicolumn{3}{|c|}{$24 \mathrm{~h}$} & \multicolumn{3}{|c|}{1 Month } \\
\hline & BOD $(\mathrm{mg} / \mathrm{L})$ & COD $(\mathrm{mg} / \mathrm{L})$ & TOC (mg/L) & BOD $(\mathrm{mg} / \mathrm{L})$ & COD $(\mathrm{mg} / \mathrm{L})$ & TOC (mg/L) \\
\hline Mahogany & $268.2 \pm 4.0$ & $1397.1 \pm 7.0$ & $699.0 \pm 5.2$ & $213.0 \pm 4.2$ & $1289 \pm 7.4$ & $647.0 \pm 7.1$ \\
\hline Cedrela & $121.7 \pm 6.0$ & $329.7 \pm 4.0$ & $167.2 \pm 6.1$ & $102.3 \pm 6.1$ & $252.2 \pm 5.5$ & $116.9 \pm 2$ \\
\hline Wawa & $31.0 \pm 3.0$ & $89.5 \pm 8.0$ & $112.5 \pm 3.3$ & $21.5 \pm 2.2$ & $59.9 \pm 4.8$ & $99.7 \pm 3.2$ \\
\hline Emire & $103.3 \pm 6.0$ & $505.3 \pm 6.0$ & $246.0 \pm 4.3$ & $94.7 \pm 6.3$ & $269.9 \pm 7.1$ & $122 \pm 3.5$ \\
\hline \multirow[t]{3}{*}{ Ceiba } & $101.1 \pm 6.0$ & $476.6 \pm 2.4$ & $200.0 \pm 6.5$ & $86.3 \pm 6.2$ & $404.6 \pm 5.3$ & $68.4 \pm 2.0$ \\
\hline & \multicolumn{3}{|c|}{3 Months } & \multicolumn{3}{|c|}{6 Months } \\
\hline & BOD $(\mathrm{mg} / \mathrm{L})$ & COD (mg/L) & TOC (mg/L) & BOD $(\mathrm{mg} / \mathrm{L})$ & COD $(\mathrm{mg} / \mathrm{L})$ & TOC (mg/L) \\
\hline Mahogany & $148.3 \pm 3.3$ & $1067.7 \pm 2.6$ & $605.1 \pm 3.5$ & $118.0 \pm 3.2$ & $1010.3 \pm 1.1$ & $476 \pm 4.3$ \\
\hline Cedrela & $93.3 \pm 6.1$ & $226.4 \pm 4.7$ & $95.8 \pm 4.2$ & $77.3 \pm 2.5$ & $207.4 \pm 1.1$ & $52.1 \pm 3.2$ \\
\hline Wawa & $16.1 \pm 2.5$ & $49.4 \pm 2.1$ & $67.3 \pm 2.4$ & $9.0 \pm 1.1$ & $37.4 \pm 4.2$ & $45.6 \pm 2.4$ \\
\hline Emire & $74.7 \pm 3.1$ & $214.2 \pm 3.4$ & $269 \pm 2.4$ & $58.1 \pm 1.3$ & $191.5 \pm 3.2$ & $219 \pm 3.1$ \\
\hline Ceiba & $69.3 \pm 2.2$ & $316.8 \pm 2.7$ & $70.6 \pm 1.3$ & $57.3 \pm 1.5$ & $274.2 \pm 1.6$ & $23.4 \pm 2.2$ \\
\hline
\end{tabular}

The COD ranged between 37.4-1397 mg/L (Table 6) and was more than 10 times the permissible level. The BOD and COD ratio was 0.3 , indicating that wood leachates can be treated biologically, but must be seeded [47]. This showed that there were more chemicals within the samples that were not oxidized [48].

The TOC measured ranges between $23.4-699 \mathrm{mg} / \mathrm{L}$ and was above the permissible limit. This indicates that the presence of organic carbons within the sample could be due to the presence of high phenols detected in wood leachates. This could promote high oxygen demand and affect lives in the aquatic environment [49].

Phenols are one of the major compounds attributed for causing toxicity in wood leachates [15,36,47]. The total phenols determined in various wood leachates ranged between $2.6-76.7 \mathrm{mg} / \mathrm{L}$ and were all above the permissible limit of $1 \mathrm{mg} / \mathrm{L}$ in wastewater [50]. Generally, phenols concentration decreased when the leachates aged. Mahogany had the highest phenol content of $76.7 \mathrm{mg} / \mathrm{L}$ at $24 \mathrm{~h}$ leachate, whereas ceiba had the lowest with $2.6 \mathrm{mg} / \mathrm{L}$ in 6 months. It could be observed that the change in phenol concentration between $24 \mathrm{~h}$ and 1 month in the various samples were not significant when compared to the change between 1 and 3 months, and 3 and 6 months. This also confirmed that age of leachate has an impact on total phenol content within leachates.

The recorded variation recorded might be due to different biochemical reactions within various wood leachates. Emire and mahogany were 33 and 66 times higher than the permissible limit, which indicated its high level of toxicity to the various aquatic organisms (Table 7). The difference in the various phenol concentrations in wood leachates could be due to their nature and species richness composition because concentration of extractives varies from tree species to tree species [51]. 
Table 7. Total phenols concentration of $24 \mathrm{~h}, 1,3$, and 6 months preparation and storage period of various wood leachates. The mean values \pm standard deviation $(n=3)$ are shown.

\begin{tabular}{ccccc}
\hline \multirow{2}{*}{ Wood Leachate } & \multicolumn{4}{c}{ Total Phenols Concentration (mg/L) } \\
\cline { 2 - 5 } & $\mathbf{2 4} \mathbf{h}$ & $\mathbf{1}$ Month & 3 Months & 6 Months \\
\hline Mahogany & $76.7 \pm 1.4$ & $75.8 \pm 4.3$ & $60.4 \pm 3.5$ & $51.6 \pm 6.0$ \\
Cedrela & $7.2 \pm 0.2$ & $7.1 \pm 0.3$ & $5.3 \pm 0.3$ & $4.7 \pm 1.2$ \\
Wawa & $8.7 \pm 0.7$ & $5.9 \pm 0.9$ & $4.8 \pm 0.5$ & $3.9 \pm 0.3$ \\
Emire & $40.1 \pm 3.1$ & $38.7 \pm 3.2$ & $29.8 \pm 2.1$ & $23.1 \pm 0.3$ \\
Ceiba & $4.1 \pm 0.4$ & $3.2 \pm 0.4$ & $2.9 \pm 0.1$ & $2.6 \pm 0.1$ \\
\hline
\end{tabular}

The concentration of phenols measured in the wood leachate samples corresponded with the level of toxicity to the aquatic organisms used for the toxicity test [15]. The high level of total phenols measured in the various wood leachates depicted that other extractives such as lignin, tannins and terpenes could be high and contribute to the toxicity of the aquatic organisms, as reported in other research work [35].

\subsection{Ecotoxicity Tests}

The toxicity of various wood leachates to algae (Desmodesmus subspicatus) were determined by cell density and growth rate of the algae after the $72 \mathrm{~h}$ of exposure. The number of living cells per volume countered after exposure increased when concentration rate decreased among all wood leachate samples. Moreover, cell density increased as wood leachates aged. An average cell density of over one million cell/mL was observed throughout all wood leachate samples. Although there was inhibition of algal growth, the number of living cells per volume in the wood leachate samples were higher than the initial inoculum of 80,000 cells $/ \mathrm{mL}$, indicating the ability of the samples to support algal growth, especially in advanced aged leachate samples. However, low numbers of living cells were recorded mostly in $67 \%$ and $100 \% v / v$ concentrations and increased to $20 \%, 30 \%$, and $45 \% v / v$ (Figures 1-3).

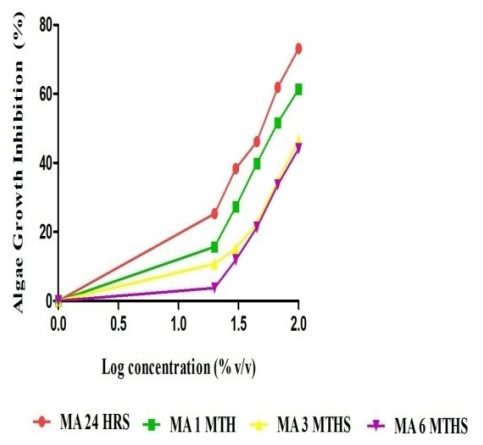

(A)

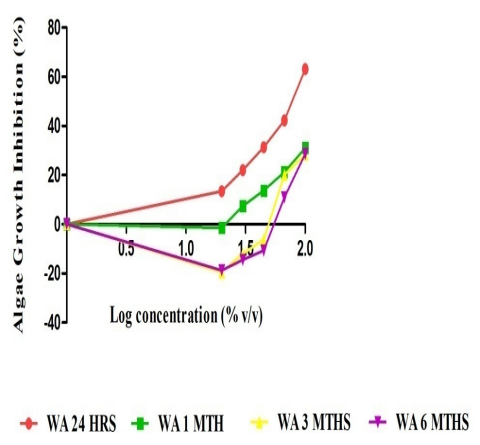

(B)

Figure 1. Percentage of algae (Desmodesmus subspicatus) growth rate inhibition upon exposure to dilution series of leachate $(20 \%, 30 \%, 45 \%, 67 \%, 100 \% v / v)$ in the various periods storage of (A) mahogany wood leachate and (B) wawa wood leachate.

The growth rate also showed a similar trend with regard to cell density, but generally the algal growth per day was high $\left(1.21 \times 10^{6}\right.$ cell/mL at 1 day $)[52,53]$.

The growth rate generally decreased as the leachate concentration increased in the various wood leachates, which indicated that to prevent the effect leachate on algal growth, the leachate has to be treated before being discharged into any aquatic system. Among all wood leachates, the mahogany leachate showed inhibition throughout the various ages, indicating inhibition of algal cells. With other leachates, there were stimulation at lower concentrations (Figure 1A) and inhibition 
at higher concentrations. This could be due to lack of nutrients that might have prevented the algae to obtain the necessary minerals for growth and color, preventing light penetration [54].

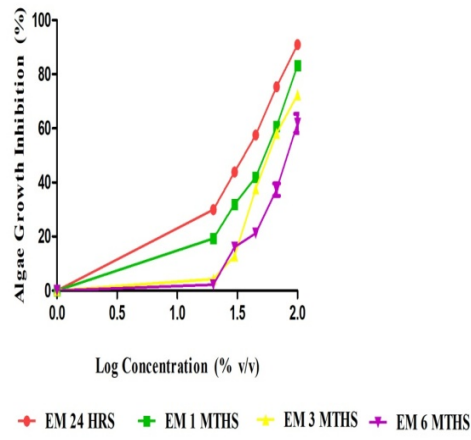

(A)

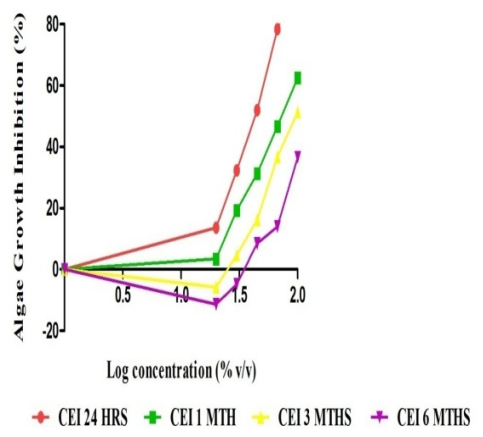

(B)

Figure 2. Percentage of algae (Desmodemus subspicatus) growth rate inhibition upon exposure to dilution series of leachate $(20 \%, 30 \%, 45 \%, 67 \%, 100 \% v / v)$ in the various storage periods of (A) emire wood leachate and (B) ceiba wood leachate.

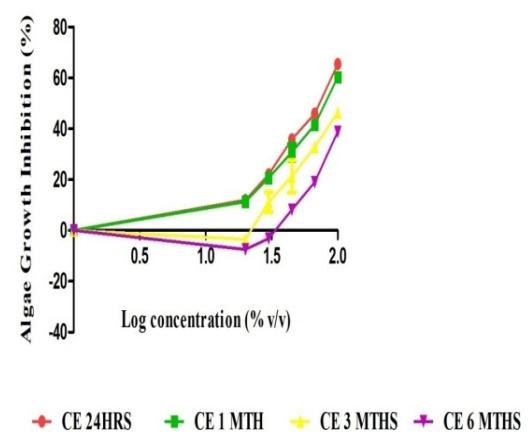

Figure 3. Percentage of algae (Desmodemus subspicatus) growth rate inhibition upon exposure to dilution series of leachate $(20 \%, 30 \%, 45 \%, 67 \%, 100 \% \mathrm{v} / \mathrm{v})$ in the various storage periods of cedrela wood leachate.

The nature of the color might have been a contributing factor because the samples became less intense when diluted with the control medium. Thus, more light transmitted at a lower concentration, enabling algae growth. High phenol levels determined in wood leachates could be a contributing factor in the inhibition of algae growth rate in the toxicity test [55]. The presence of phenols caused cell and tissue damage in the samples, altering intermediary metabolisms and oxidative stress [56]. The variations in conductivity and high BOD, COD, and TOC might also be a contributing factor, because algae needs optimal conditions to thrive [48]. High conductivity levels in the samples could create osmotic pressure and affect water absorption by the algae, thus affecting their growth rate. High BOD, COD, and TOC could affect algae growth rate because of too much organic matter, which may result in less oxygen availability, thereby depicting more growth recorded as the leachate aged in the algal toxicity test [57].

The high levels of metals measured in leachates may also affect the growth and photosynthesis of algae. The absence of $\mathrm{Zn}$ in all leachates is a basic component of various enzymes involved in photosynthesis and metabolism. The presence of other heavy metals such as $\mathrm{Cd}, \mathrm{Cr}$, and $\mathrm{Mn}$ in leachates could have resulted in algae inhibition [58].

The dose-response curve of algae growth in various wood leachates showed distinct trends with respect to leachate age. The dose-response indicated a reduction in response to the algae as the leachate aged (Figures 1-3). In mahogany and wawa, there was not much of a difference between 3 and 6 months (Figure 1). For cedrela (Figure 3), there was not much of a dose-response difference between the $24 \mathrm{~h}$ and $1 \mathrm{month}$ leachates. For emire, even though there was a difference in the dose-response of 
the algae at various leachate ages, at $67 \% v / v$ almost the same dose-response was realized in the 1 and 3 month(s) leachates (Figure 2A). These variations in dose-response could be due to the phenols in the wood leachates, or biochemical processes that took place during storage or response during the exposure period [35,59].

The percentage median $\mathrm{IC}_{50}$ of wood leachate samples for algae (Desmodesmus subspicatus) ranged between $27.7-60.0 \%$ (Table 8 ), which depicted both confirmed and potential toxicity $[60,61]$. This proves that the various wood leachates had negative effects on algae growth at different toxicity levels. Thus, when released into the environment without treatment it could impact the aquatic environment. The mahogany showed the highest toxicity with a \% IC 50 value of $27.7 \%$ at $24 \mathrm{~h}$. Wawa had the lowest toxicity with a $\% \mathrm{IC}_{50}$ value of $60 \%$ at 6 months. It was observed that the $\% \mathrm{IC}_{50}$ reduced when leachates aged.

Table 8. The percentage median inhibition concentration $\left(\% \mathrm{IC}_{50}\right)$ values for the toxicity of $24 \mathrm{~h}, 1,3$, and 6 months of storage period for various wood leachates to algae (Desmodemus subspicatus) growth rate.

\begin{tabular}{ccccc}
\hline \multirow{2}{*}{ Wood Leachates } & \multicolumn{4}{c}{ Leachate Age } \\
\cline { 2 - 5 } & $\mathbf{2 4 ~ \mathbf { ~ }}$ & 1 Month & 3 Months & 6 Months \\
\cline { 2 - 5 } & \multicolumn{2}{c}{ \% IC of Growth Rate of Desmodesmus } & subspicatus \\
\hline Mahogany & 27.70 & 36.56 & 40.24 & 50.63 \\
Cedrela & 40.54 & 41.47 & 44.57 & 56.64 \\
Wawa & 41.53 & 46.47 & 51.67 & 60.00 \\
Emire & 30.64 & 39.03 & 44.47 & 52.38 \\
Ceiba & 38.64 & 43.34 & 49.54 & 54.88 \\
\hline
\end{tabular}

The growth rate of duckweed in the wood leachate was determined using frond numbers (pcs), frond area $\left(\mathrm{cm}^{2}\right)$, and chlorophyll content $\left(\mu \mathrm{g} / \mathrm{cm}^{2}\right)$. The duckweed fronds ranged between 16-18 fronds in almost all wood leachates on the third day of exposure, except in the mahogany leachates, where the frond number was below 14 . Even in some aged leachates, wawa, ceiba, and cedrela doubled their frond number on the third day of exposure. Usually, increased frond numbers are seen at lower leachate concentrations. On the seventh day of exposure, the number of fronds ranged between 25-32. This was realized in the $20 \%, 30 \%$, and $45 \% v / v$ concentrations. In the higher concentrations, it ranged between 18 and 19 fronds, especially in the mahogany and emire leachates.

Most samples showed stimulation, chloritic, or necrotic nature of fronds throughout various ages (Figure 4). In the aged leachates, the frond number tripled in mahogany, emire, and cedrela leachates, and even quadrupled in wawa and ceiba leachates, especially after exposure to lower concentrations. The duckweed frond area increased by $0.6 \mathrm{~cm}^{2}$ on the third day in almost all leachates except mahogany, which was $0.3 \mathrm{~cm}^{2}$ at its lower concentrations. On the seventh day of exposure, the frond area in the lower concentrations increased by $0.13 \mathrm{~cm}^{2}$ and at the higher concentration by $0.5 \mathrm{~cm}^{2}$. The chlorophyll content of the duckweed after exposure increased as concentrations decreased. The average chlorophyll content in the control was $18 \mu \mathrm{g} / \mathrm{cm}^{2}$ and that of the various samples was $9.8 \mu \mathrm{g} / \mathrm{cm}^{2}$, indicating that the chlorophyll content in the control was two times more than the samples. The mahogany leachate had the lowest chlorophyll content at $100 \% v / v$, which was $0.2 \mu \mathrm{g} / \mathrm{cm}^{2}$. This correlates to the necrotic nature of the fronds observed during the experiment. The low chlorophyll content observed in some of these leachates might be due to many chemical or enzymatic degradation reactions during the exposure period [62]. There was duckweed stimulation in almost all wood leachate concentrations except for mahogany, which chlorosis and necrosis of fronds were observed.

High growth rate was recorded in wawa, cedrela, and ceiba at 20\%, 30\&, and $45 \% v / v$. For emire and mahogany, it was observed in $20 \%$ and $30 \% v / v$ concentrations throughout all wood leachates. The highest inhibition of duckweed was seen in mahogany leachates and the lowest in wawa. This could be due to the lack of nutrients, high phenol concentration, and metals from the leachate, which may have affected duckweed growth and development $[63,64]$. The lack of nutrients was largely due to 
absence of a nutritive control medium in the $100 \% v / v$ and small amount in the $67 \% v / v$, which would not have been sufficient to support duckweed growth. Duckweed root elongation was observed in high concentrations and short roots were seen in lower concentrations. This could be due to lack of nutrients and thus the duckweed's extending roots could be used to obtain limited nutrients within the sample. The high level of phenol concentration may have affected the growth and development of duckweed because it affected metabolism and interfered with various enzyme activities.

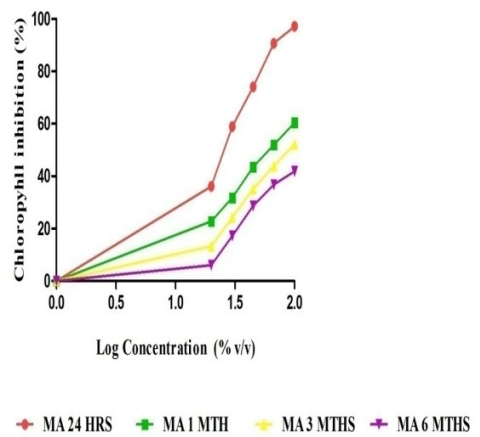

(A)

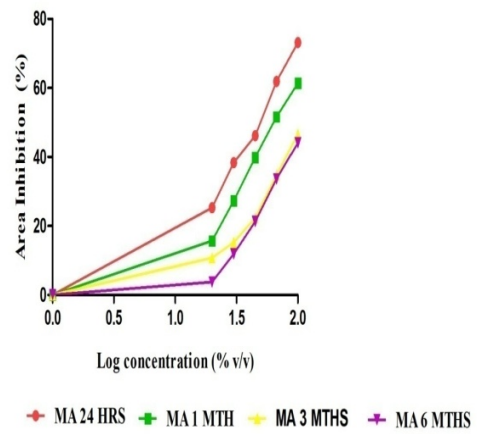

(B)

Figure 4. Percentage inhibition of chlorophyll content (A) and area (B) of duckweed (Lemna minor) fronds upon exposure to dilution series of leachate $(20 \%, 30 \%, 45 \%, 67 \%$, and $100 \% v / v)$ in the various storage periods of the mahogany wood leachate.

The chlorotic fronds of duckweed observed in most samples indicated a possible toxicity of chemicals such as Mn, which were detected in all wood samples and may have affected the growth and development of the duckweed [65].

$\mathrm{Cd}$ and $\mathrm{Cu}$ may have caused genotoxicity and oxidative stress in duckweed [66]. Cd might have contributed to the toxicity of the duckweed by destroying the photosynthesis apparatus and nitrogen metabolism, thus resulting in growth retardation [67]. The chlorosis, necrosis, and frond discoloration of duckweed observed in the leachates could be due to the presence of $\mathrm{Cu}$ [68]. The presence of $\mathrm{Cr}$ may have caused growth rate reduction and content of photosynthetic pigments [69]. The variation in $\mathrm{pH}$ and conductivity of the leachate could affect mineral transportation and also build osmotic pressure within the system, especially around the roots. This affects water absorption and duckweed growth and development.

The growth rate increased as concentrations decreased: $100>67>45>30>20 \% v / v$ and the effect of the leachates to duckweed decreased as they aged, which could be due to their biochemical reaction that occurred during the exposure period. The dose-response curve for both chlorophyll and area inhibition showed a similar growth rate trend for duckweed. However, for mahogany, there was an inhibition for both the chlorophyll and the area inhibition, with $24 \mathrm{~h}$ leachate depicting almost all fronds as necrotized. The area inhibition curve of mahogany showed no difference between the 3 and 6 months leachate, which could be due to them having almost the same area. The difference in chlorophyll inhibition could be due to level of decolorization of their fronds after exposure.

There was stimulation in all lechate types (Figures 4-8) observed at 3 and 6 months in the area and chlorophyll content, with $24 \mathrm{~h}$ and 1 month leachates showing inhibition. The various wood leachates at $24 \mathrm{~h}$ showed a high inhibition to the duckweed at the 100\% v/v concentration, which indicated that when raw leachates were released into water body, duckweed growth was seriously impacted. The $\%$ $\mathrm{IC}_{50}$ of the chlorophyll content and duckweed area decreased as the wood leachate aged. 


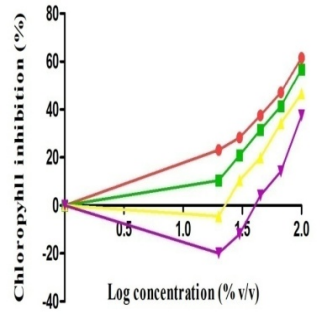

+ CE 24 HRS + CE 1 NTH + CE 3 NTHS + CE 6 MTHS

(A)

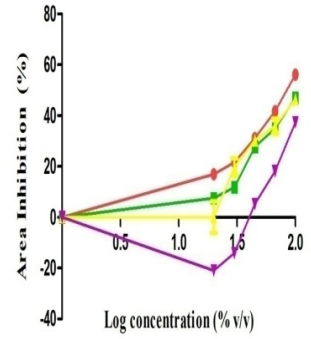

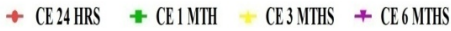

Figure 5. Percentage inhibition of chlorophyll content (A) and area (B) of duckweed (Lemna minor) fronds upon exposure to dilution series of leachate $(20 \%, 30 \%, 45 \%, 67 \%$, and $100 \% v / v)$ in the various storage periods of cedrela wood leachates.

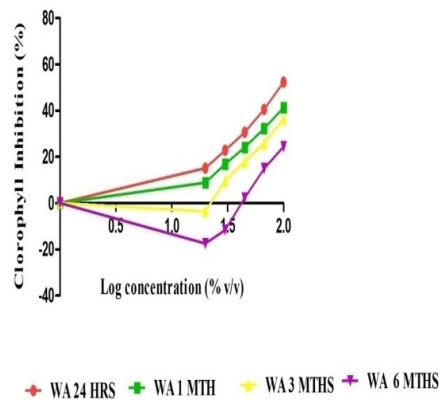

(A)

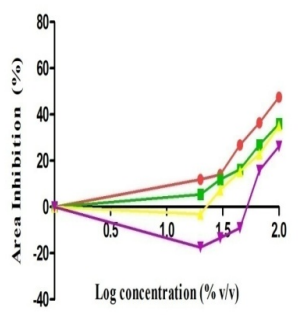

+ WA24HRS + WA1MTH - WA3MTHS + WA6MTHS

(B)

Figure 6. Percentage inhibition of chlorophyll content (A) and area (B) of duckweed (Lemna minor) fronds upon exposure to dilution series of leachate $(20 \%, 30 \%, 45 \%, 67 \%$, and $100 \% v / v)$ in the various storage periods of emire wood leachates.

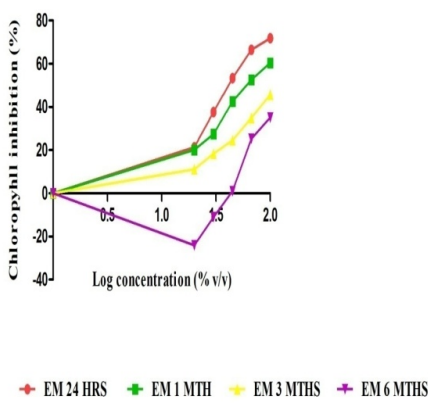

(A)

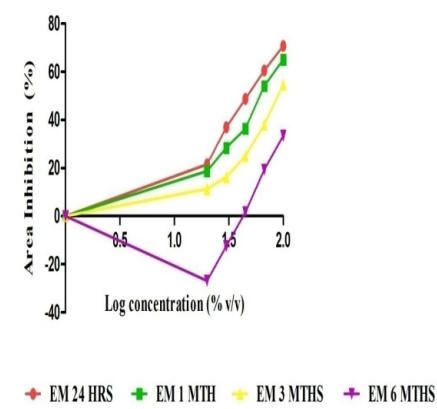

(B)

Figure 7. Percentage inhibition of chlorophyll content (A) and area (B) of duckweed (Lemna minor) fronds upon exposure to dilution series of leachate $(20 \%, 30 \%, 45 \%, 67 \%$, and $100 \% v / v)$ in the various storage periods of emire wood leachates.

The duckweed toxicity test indicated that the size of the front area after exposure correlated with the quantity of chlorophyll content. Stimulation was observed in the emire leachate only at 6 months and similar dose-response between the $24 \mathrm{~h}$ and 1 month of the 20\% $v / v$ concentration after exposure (Figure 7). 


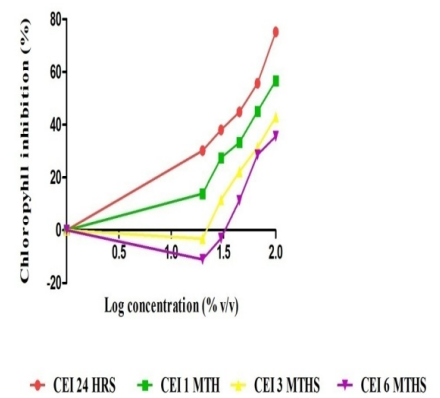

(A)

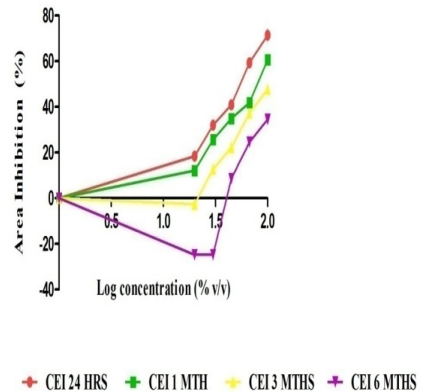

(B)

Figure 8. Percentage inhibition of chlorophyll content (A) and area (B) of duckweed (Lemna minor) fronds upon exposure to dilution series of leachate $(20 \%, 30 \%, 45 \%, 67 \%$, and $100 \% v / v)$ in the various storage periods of ceiba wood leachates.

This then indicated that leachates toxicity towards duckweed decreased as leachates were stored over a longer period. The $\% \mathrm{IC}_{50}$ of duckweed chlorophyll content ranged between $25.2-57.2 \%$ among the various ages of leachates (Table 9 ). Mahogany leachate had the highest toxicity with a $\% \mathrm{IC}_{50}$ value of $25.2 \%$ in the $24 \mathrm{~h}$ leachate, whereas wawa leachate the lowest toxicity with a \% $\mathrm{IC}_{50}$ value of $57.2 \%$ for the 6 month leachate. The $\% \mathrm{IC}_{50}$ for the frond area of duckweed ranged between $29.1-50.1 \%$ (Table 9). The highest $\% \mathrm{IC}_{50}$ was realized in mahogany with a $\% \mathrm{IC}_{50}$ of $29.1 \%$, whereas the was cedrela, for the 6 month leachate. The $\% \mathrm{IC}_{50}$ ranged of the various bioindicators depicted that the leachates confirmed the potential toxicity $[60,61]$.

Table 9. The $\% \mathrm{IC}_{50}$ values for the toxicity of $24 \mathrm{~h}, 1,3$, and 6 months storage period of various wood leachates to duckweed (Lemna minor) frond area and chlorophyll content.

\begin{tabular}{|c|c|c|c|c|c|c|c|c|}
\hline \multirow{4}{*}{ Wood Leachates } & \multicolumn{8}{|c|}{ Leachate Age } \\
\hline & \multicolumn{8}{|c|}{ \% IC of Lemna minor Frond Area and Chlorophlly Content (a and b) } \\
\hline & \multicolumn{2}{|c|}{$24 \mathrm{~h}$} & \multicolumn{2}{|c|}{1 Month } & \multicolumn{2}{|c|}{3 Months } & \multicolumn{2}{|c|}{6 Months } \\
\hline & $\begin{array}{c}\text { Frond } \\
\text { Area }\end{array}$ & $\begin{array}{l}\text { Chlorophyll } \\
\text { Content } \\
\text { (a and b) }\end{array}$ & $\begin{array}{c}\text { Frond } \\
\text { Area }\end{array}$ & $\begin{array}{l}\text { Chlorophyll } \\
\text { Content } \\
\text { (a and b) }\end{array}$ & $\begin{array}{c}\text { Frond } \\
\text { Area }\end{array}$ & $\begin{array}{c}\text { Chlorophyll } \\
\text { Content } \\
\text { (a and b) }\end{array}$ & $\begin{array}{c}\text { Frond } \\
\text { Area }\end{array}$ & $\begin{array}{c}\text { Chlorophyll } \\
\text { Content } \\
\text { (a and b) }\end{array}$ \\
\hline Mahogany & 29.15 & 25.23 & 32.82 & 27.16 & 41.00 & 32.02 & 44.06 & 34.45 \\
\hline Cedrela & 36.11 & 30.83 & 41.21 & 39.06 & 37.33 & 44.57 & 50.17 & 52.73 \\
\hline Wawa & 34.02 & 34.02 & 36.32 & 36.32 & 42.66 & 42.66 & 47.03 & 57.03 \\
\hline Emire & 29.38 & 28.58 & 34.03 & 29.91 & 43.65 & 37.12 & 45.55 & 46.23 \\
\hline Ceiba & 34.13 & 29.13 & 37.58 & 33.62 & 43.38 & 42.18 & 44.67 & 45.20 \\
\hline
\end{tabular}

Zooplankton species D. magna was used for the toxicity test because of its importance in the ecosystem. In the toxicity test, D. magna endpoints were used for reproduction, growth, survival, and death or immobilization. In the present study, the immobilization of $D$. magna was used as the endpoint after $48 \mathrm{~h}$ of exposure. Immobilization was recorded in all wood leachates and for juveniles, immobilization increased as concentration increased. Moreover, we observed that the immobilization of juveniles decreased as leachates aged after exposure. In mahogany leachate, all juveniles were immobilized with a $100 \% v / v$ concentration, regardless of age. Immobilization was recorded in $67 \%$ and $45 \% \mathrm{v} / \mathrm{v}$ concentrations in the $24 \mathrm{~h}$ leachate and in the 1 month leachate at $67 \% \mathrm{v} / \mathrm{v}$. The $20 \%, 30 \%$, and $45 \% v / v$ of the various ages of the mahogany leachates showed mobility of juveniles between 2-3 juveniles after exposure. For cedrela, all juveniles immobilized after $24 \mathrm{~h}$ and 1 month at $67 \%$ and $100 \% v / v$ concentrations. The juveniles were all mobile in 6 months leachates. In $20 \%, 30 \%$, and $45 \% v / v$ concentrations, the number of juveniles alive within the various ages of the cedrela leachate ranged between 3-5 juveniles. Wawa leachates had no immobilization of juveniles in the 1,3 , and 6 months. Immobilization in the wawa leachate was observed in the $24 \mathrm{~h}$ leachate at $67 \%$ and $100 \% v / v$ concentration with 1-2 juveniles immobilized. The immobilization of all juveniles was 
observed at $100 \% v / v$ concentration for all ages of emire leachates. Further, for emire, at $30 \%, 45 \%$, and $67 \% v / v$ concentrations $2-4$ mobile juveniles were observed in each beaker and no immobilization was recorded in $20 \%$ and $30 \% v / v$ for 3 and 6 months leachates. In the ceiba leachates, immobilization was observed at $100 \% v / v$ concentration in every wood leachates understudy and also through $67 \% v / v$ concentration, except in the 6 months leachate, where juvenile mobility was observed. Furthermore, juvenile mobility was recorded at $20 \%, 30 \%$, and $45 \% v / v$ in the various leachate ages, which ranged between 3-4 juveniles. The changes in immobilization occurred in the leachates and cold be due to their different chemical composition and biological nature. The reduction in immobilization could be due to biochemical reactions that occurred during the storage of leachates and also during the period of the exposure. The high immobilization recorded in most leachates could be due to the presence of inorganic compounds, i.e., $\mathrm{Mn}, \mathrm{Cr}$, and $\mathrm{Cu}$ [70,71]. Dissolved oxygen concentrations measured after the experiments in the various leachates were above $5 \mathrm{mg} / \mathrm{L}$. The $\mathrm{pH}$ after exposure ranged between 5.1-8.1 and largely fell within the optimal $\mathrm{pH}$ for survival and growth of daphnia. However, $\mathrm{pH}$ variation for leachates, especially emire and mahogany, might have contributed to the immobilization of daphnia [72]. The high levels of phenol measured in the leachates could have a biological effect on the juveniles, potentially resulting in their immobilization [73]. The presence of heavy metals within the leachates might cause chemotoxicity, which can result in daphnia mortality.

All wood leachates showed $100 \%$ immobilization at $100 \% v / v$ concentration at $24 \mathrm{~h}$, except in wawa, which depicted $60 \%$ immobilization. This indicates that fresh leachates are highly toxic to daphnia. At 20\% v/v,0\% immobilization was recorded in all wood leachates except mahogany, which recorded 20\% immobilization (Figures 9-11). Moreover, \% immobilization was recorded in other concentrations in the ages of various leachates between $20-100 \%$, but in wawa $0 \%$ immobilization was observed in these concentrations. The variation observed in the various leachates could be due to chemical composition and biochemical reaction during the storage and exposure period. Furthermore, the high concentration of phenol could also be a contributing factor.

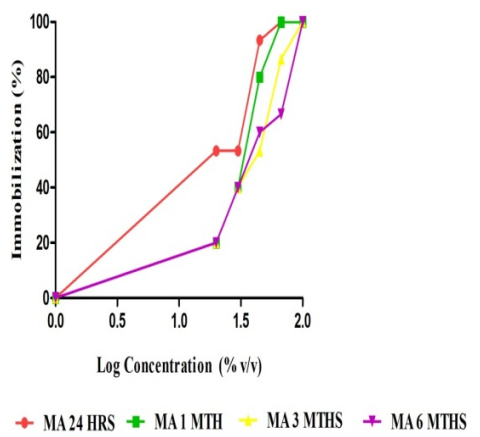

(A)

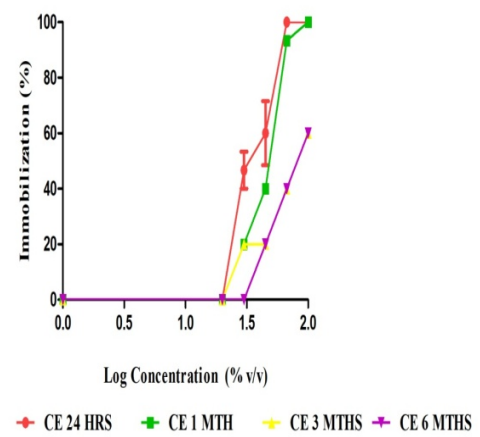

(B)

Figure 9. Percentage of daphnia (Daphnia magna) immobilization upon exposure to dilution series of leachate $(20 \%, 30 \%, 45 \%, 67 \%$, and $100 \% \mathrm{v} / \mathrm{v})$ in the various storage periods of mahogany (A) and cedrela (B) wood leachates.

Mahogany had the highest $\% \mathrm{IC}_{50}$ at $21.5 \%$ for the $24 \mathrm{~h}$ leachate and wawa had the lowest toxicity of $\% \mathrm{IC}_{50}$ at $67.5 \%$ for the 6 month leachate (Table 10). The $\% \mathrm{IC}_{50}$ decreased as the wood leachate increased. Mahogany leachates showed confirmed toxicity throughout all ages, proving that the leachate is toxic irrespective of age. The emire, cedrela, ceiba, and wawa showed potential toxicity, which proved they all have the tendency to cause toxic effect to daphnia at different toxicity levels [60,61]. 


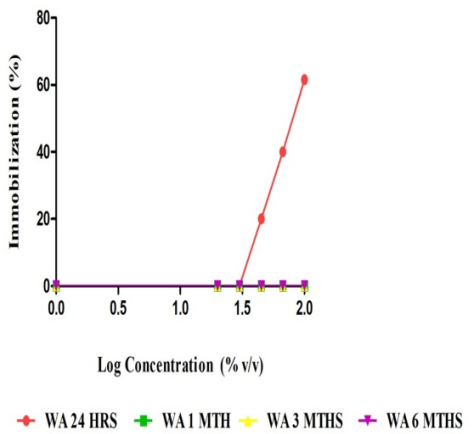

(A)

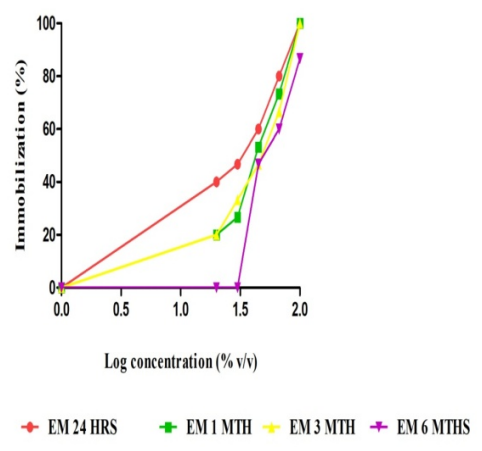

(B)

Figure 10. Percentage of daphnia (Daphnia magna) immobilization upon exposure to dilution series of leachate $(20 \%, 30 \%, 45 \%, 67 \%$, and $100 \% \mathrm{v} / \mathrm{v})$ in the various storage periods of wawa (A) and emire (B) leachates.

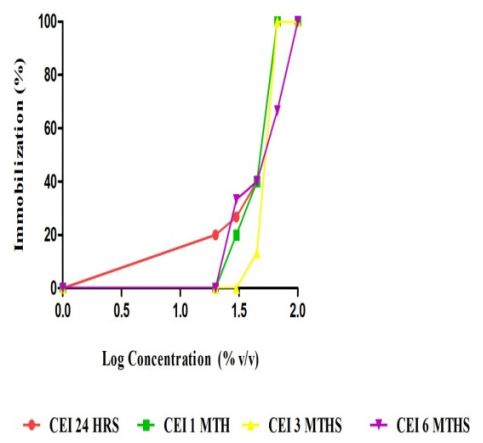

Figure 11. Percentage of daphnia (Daphnia magna) immobilization upon exposure to dilution series of leachate $(20 \%, 30 \%, 45 \%, 67 \%$, and $100 \% \mathrm{v} / \mathrm{v})$ in the various storage periods of ceiba wood leachates.

Table 10. $\% \mathrm{IC}_{50}$ values for the toxicity of $24 \mathrm{~h}, 1,3$, and 6 Months storage period of various wood leachates to immobilization of Daphnia magna.

\begin{tabular}{ccccc}
\hline \multirow{2}{*}{ Wood Leachates } & \multicolumn{4}{c}{ LEACHATE AGE } \\
\cline { 2 - 5 } & $\mathbf{2 4} \mathbf{h}$ & 1 Month & 3 Months & 6 Months \\
\cline { 2 - 5 } & \multicolumn{2}{c}{ \% IC of Immobilization of Daphnia } & magna \\
\hline Mahogany & 21.51 & 31.79 & 36.84 & 37.94 \\
Cedrela & 35.33 & 46.16 & 49.88 & 54.90 \\
Wawa & 55.61 & 60.14 & 64.97 & 67.77 \\
Emire & 29.80 & 41.88 & 43.08 & 48.36 \\
Ceiba & 42.35 & 45.95 & 46.35 & 47.80 \\
\hline
\end{tabular}

\section{Conclusions}

Our study of aged wood leachates showed various toxicity levels for the test organisms. We determined that high BOD, COD, and TOC, as well as metals and high levels of phenols, might cause toxicity in test organisms. Toxicity decreased when wood aged in various leachate samples. Among the studied sampls, the mahogany leachate was the most toxic, while wawa was the least toxic. The $\% \mathrm{IC}_{50}$ ranged between $21.51 \%$ and $66.77 \%$, indicating both confirmed and potential toxicity to aquatic organisms. The mahogany leachates showed the highest $\% \mathrm{IC}_{50}$ of $21.51 \%$ in the $24 \mathrm{~h}$ leachate, whereas wawa shoes the lowest with a $\% \mathrm{IC}_{50}$ of $66.77 \%$. The present study confirms that in natural products like wood, leachate is toxic in early stages but reduces toxicity due to biological activities. The result obtained can be used by policymakers for environmental management. The results further 
will help environmental engineers design wood leachate treatment facilities. The results will serve as a basis for other researchers on further study of wood leachate toxicity.

Author Contributions: L.N.A.S. conceived the research idea, L.N.A.S. and K.A.M. eastablished the research methodology, L.N.A.S. performed the formal analysis and investigations, L.N.A.S. drafted the original preparation, K.A.M. and V.K. did the review and editing and V.K. and K.A.M. did the supervision. All authors have read and agreed to the published version of the manuscript.

Funding: This research received no external funding.

Acknowledgments: Authors would like to acknowledge scientific internal grant agency of University of Chemistry and Technology (UCT) Prague for funding this study and its institutional support.

Conflicts of Interest: The authors declare that they have no competing interests.

\section{References}

1. Garbowski, T. Changes in the physico-chemical parameters of water as a result of long-term contact with biomass, on the example of pine bark (Pinus sylvestris). Water Air Soil Pollut. 2019, 230, 140. [CrossRef]

2. Taylor, B.N.; Goudey, J.S.; Carmichael, N.B. Toxicity of aspen wood leachate to aquatic life: Laboratory studies. Environ. Toxicol. Chem. 1996, 15, 150-159. [CrossRef]

3. Naselli-Flores, L.; Barone, R. Fight on plankton! Or, phytoplankton shape and size as adaptive tools to get ahead in the struggle for life. Cryptogam. Algol. 2011, 32, 157-204. [CrossRef]

4. Pal, R.; Choudhury, A.K. An Introduction to Phytoplanktons: Diversity and Ecology. 2014. Available online: https://www.springer.com/gp/book/9788132218371 (accessed on 17 February 2020).

5. Omar, W.M. Perspectives on the use of algae as biological indicators for monitoring and protecting aquatic environments, with special reference to malaysian freshwater ecosystems. Trop. Life Sci. Res. 2010, 21, 51-67. [PubMed]

6. Kaczala, F.; Salomon, P.S.; Marques, M.; Granéli, E.; Hogland, W. Effects from Log-Yard Stormwater Runoff on the Microalgae Scenedesmus Subspicatus: Intra-Storm Magnitude and Variability. J. Hazard. Mater. 2011, 185, 732-739. [CrossRef] [PubMed]

7. Skillicorn, P.; Spira, W.; Journey, W. Duckweed Aquaculture: A New Aquatic Farming System for Developing Countries; The World Bank: Washington, DC, USA, 1993; Available online: https://www.researchgate.net/publication/ 242631709_Duckweed_Aquaculture_A_New_Aquatic_Farming_System_for_Developing_Countries (accessed on 2 March 2020).

8. Bernard, F.A.; Bernard, J.M.; Denny, P. Flower structure, anatomy and life history of Woiffiia australiana (Benth.) den Hartog \& van der Plas. Bull. Torrey Bot. Club 1990, 117, 18-26.

9. Fekete-Kertész, I.; Kunglné-Nagy, Z.; Gruiz, K.; Magyar, Á.; Farkas, É.; Molnár, M. Assessing toxicity of organic aquatic micropollutants based on the total chlorophyll content of Lemna minor as a sensitive endpoint. Period. Polytech. Chem. Eng. 2015, 59, 262-271. [CrossRef]

10. Moody, M.; Miller, J. Lemna minor Growth Inhibition Test. In Small-Scale Freshwater Toxicity Investigations; Blaise, C., Férard, J.F., Eds.; Springer: Dordrecht, The Netherlands, 2005; pp. 271-298.

11. Bednarova, I.; Mikulaskova, H.; Havelkova, B.; Strakova, L.; Beklova, M.; Sochor, J.; Hynek, D.; Adam, V.; Kizek, R. Study of the influence of platinum, palladium and rhodium on duckweed (lemna minor). Neuro Endocrinol. Lett. 2004, 35, 35-42.

12. Clare, J.P. Daphnia: An Aquarist's Guide, Version 3.2; 2002. Available online: https://digitalcommons.ithaca. edu/cgi/viewcontent.cgi?article=1614\&context=whalen (accessed on 13 February 2020).

13. Svendsen, N.; Reisser, C.M.O.; Dukić, M.; Thuillier, V.; Ségard, A.; Liautard-Haag, C.; Fasel, D.; Hürlimann, E.; Lenormand, T.; Galimov, Y.; et al. Uncovering cryptic asexuality in daphnia magna by rad sequencing. Genetics 2015, 201, 1143-1155. [CrossRef]

14. Göran, D.; Pia, A. Comparative toxicity of leachates from 52 textiles to Daphnia magna. Ecotoxicol. Environ. Saf. 2010, 73, 1629-1632.

15. Taylor, B.R.; Carmichael, N.B. Toxicity and chemistry of aspen wood leachate to aquatic life: Field study. Environ. Toxicol. Chem. 2003, 22, 2048-2056. [CrossRef] [PubMed]

16. Sackey, L.N.A.; Kočí, V.; van Gestel, C.A.M. Ecotoxicological effects on Lemna minor and Daphnia magna of leachates from differently aged landfills of Ghana. Sci. Total Environ. 2020, 698, 134295. [CrossRef] [PubMed] 
17. ISO 11465. Soil Quality—Determination of Dry Matter and Water Content on a Mass Basis—Gravimetric Method; ISO: Brussel, Belgium, 1993.

18. Sackey, L.N.A.; Kočí, V. Assessing the effects of tropical wood leachate to Desmodesmus subspicatus, Lemna minor and Daphnia magna. Heliyon 2020, 6, e04268. [CrossRef] [PubMed]

19. Standard Method for Examination of Wastewater 5210 Biochemical Oxygen Demand (BOD). 2017. Available online: https://www.standardmethods.org/doi/10.2105/SMWW.2882.102 (accessed on 16 March 2020).

20. Chubaka, C.E.; Whiley, H.; Edwards, J.W.; Ross, K.E. Lead, Zinc, Copper, and Cadmium Content of Water from South Australian Rainwater Tanks. Int. J. Environ. Res. Public Health 2018, 15, 1551. [CrossRef]

21. Environmental Protection Agency. The Determination of Chemical Oxygen Demand by Semi Automated Colorimetry; Method 410.4, Revision 2.0; 1993. Available online: https://www.epa.gov/sites/production/files/2015-08/ documents/method_410-4_1993.pdf (accessed on 20 April 2020).

22. Standard Method for Examination of Wastewater 5310 Total Organic Carbon (TOC). 2017. Available online: https://www.standardmethods.org/doi/10.2105/SMWW.2882.104 (accessed on 16 March 2020).

23. Singleton, V.L.; Rossi, J.A. Colorimetry of total phenolics with phosphomolybdic-phosphotungstic acid reagents. Am. J. Enol. Vitic. 1965, 16, 144-158.

24. Bold, H.C. The morphology of Chlamydomonas chlamydogama sp. nov. Bull. Torrey Bot. Club 1949, 76, 101-108. [CrossRef]

25. ISO 8692. Water Quality_Fresh Water Algal Growth Inhibition Test with Unicellular Green Algae; ISO: Brussel, Belgium, 2012.

26. OECD Guidelines for the Testing of Chemicals Proposal for Updating Guideline 201 Freshwater Algae and Cyanobacteria, Growth Inhibition Test; OECD: Paris, France, 2002; Available online: https:/www.oecd.org/Chemicalsafety/ testing/1946914.pdf (accessed on 15 March 2020).

27. ISO/FDIS 20079. Water Quality Determination of the Toxic Effect of Water Constituents and Waste Water on Duckweed (Lemna minor). Duckweed Growth Inhibition Test; Final Draft; ISO: Geneva, Switzerland, 2005; Available online: https://www.iso.org/obp/ui/\#iso:std:67326:en (accessed on 18 April 2020).

28. OECD Guidelines for the Testing of Chemicals Revised Proposal for a New Guideline 221 Lemna sp. Growth Inhibition Test; OECD: Paris, France, 2002; Available online: http://www.oecd.org/chemicalsafety/testing/1948054.pdf (accessed on 18 April 2020).

29. Wellburn, A.R. The spectral determination of chlorophyll a and chlorophyll $\mathrm{b}$ as well as total carotenoids, using various solvents with spectrophotometers of different resolution. J. Plant Physiol. 1994, 144, 307-313. [CrossRef]

30. NIS Elements ver. 4.2. Laboratory imaging Prague, Czech Republic. 2014. Available online: https://www.niselements.cz/ (accessed on 12 March 2020).

31. ISO 6341. Water Quality-Determination of the Inhibition of Mobility of Daphnia Magna Straus (Cladocera, Crustacea)-Acute Toxicity Test; ISO: Geneva, Switzerland, 1996; Available online: https://www.iso.org/ standard/21923.html (accessed on 18 April 2020).

32. OECD Guidelines for the Testing of Chemicals 202 Daphnia sp. Acute Immobilisation Test; OECD: Paris, France, 2004; Available online: http://www.oecd.org/chemicalsafety/testing/46507550.pdf (accessed on 18 April 2020).

33. Klüttgen, B.; Dulmer, U.; Engels, M.; Ratte, H.T. ADaM, an artificial freshwater for the culture of Zooplankton. Water Res. 1994, 28, 743-746. [CrossRef]

34. GraphPad Prism; ver. 5.01; GraphPad Software Inc.: La Jolla, CA, USA, 2009.

35. Tao, W.; Hall, K.J.; Masbough, A.; Frankowsk, K.; Duff, S.J.B. Characterization of leachate from a wood waste pile. Water Qual. Res. J. Can. 2005, 40, 476-483. [CrossRef]

36. Svensson, H. Leaching Test with Sawdust from Different Tree Species Appropriateness of Using Them as Adsorption Media in Wastewater and in Storm Water Treatment. Master's Thesis, Linnaeus University, Växjö, Sweden, 2010.

37. Nyame, F.K.; Tigme, J.; Kutu, J.M.; Armah, T. Environmental Implications of the Discharge of Municipal Landfill Leachate into the Densu River and Surrounding Ramsar Wetland in the Accra Metropolis, Ghana. J. Water Resour. Prot. 2012, 4, 622. [CrossRef]

38. Gray, N.F. Water Science and Technology: An Introduction; Taylor \& Francis, CRC Press: Boca Raton, FL, USA, 2017.

39. Clark, R.B. Plant response to mineral element toxicity and deficiency. In Breeding Plants for Less Favorable Environments; Christiansen, M.N., Lewis, C.F., Eds.; John Wiley \& Sons: New York, NY, USA, 1982; pp. 71-142. 
40. Bailey, H.C.; Elphick, J.R.; Potter., A.; Chao, E.; Konasewich, D.; Zak, J.B. Causes of toxicity in stormwater runoff from sawmills. Environ. Toxicol. Chem. 1999, 18, 1485-1491. [CrossRef]

41. World Health Organization. Guidelines for Drinking-Water Quality, 4th ed.; WHO: Geneva, Switzerland, 2011.

42. Andresen, E.; Küpper, H. Cadmium toxicity in plants. Met. Ions Life Sci. 2013, 11, 395-413. [PubMed]

43. Huang, M.; Zhu, H.; Zhang, J.; Tang, D.; Han, X.; Chen, L.; Du, D.; Yao, J.; Chen, K.; Sun, J. Toxic effects of cadmium on tall fescue and different responses of the photosynthetic activities in the photosystem electron donor and acceptor sides. Sci. Rep. 2017, 7, 14387. [CrossRef]

44. Shanker, A.K.; Cervantes, C.; Loza-Tavera, H.; Avudainayagam, S. Chromium toxicity in plants. Environ. Int. 2005, 31, 739-753. [CrossRef]

45. Igiri, B.E.; Okoduwa, S.I.R.; Idoko, G.O.; Akabuogu, E.P.; Adeyi, A.O.; Ejiogu, I.K. Toxicity and bioremediation of heavy metals contaminated ecosystem from tannery wastewater: A Review. J. Toxicol. 2018, 2018, 2568038. [CrossRef]

46. Atici, T.; Obali, O.; Altindag, A.; Ahhiska, S.; Aydin, D. The accumulation of heavy metals (Cd, Pb, Hg, Cr) and their state in phytoplanktonic algae and zooplanktonic organisms Beysehir Lake and MOgan Lake, Turkey. Afr. J. Biotechnol. 2010, 9, 475-487.

47. Khaled, Z.A.; Gina, H. Correlation between biochemical oxygen demand and chemical oxygen demand for various wastewater treatment plants in Egypt to obtain the biodegradability indices. Int. J. Sci. Basic Appl. Res. 2014, 13, 42-48.

48. Rex, F.J.; Dube, S.; Kruskopf, P.; Berch, S. Investigating potential toxicity of leachate from wood chip piles generated by roadside biomass operations. Forests 2016, 7, 40. [CrossRef]

49. Kannepalli, S.; Strom, P.F.; Krogmann, U.; Subroy, V.; Giménez, D.; Miskewitz, R. Characterization of wood mulch and leachate/runoff from three wood recycling facilities. J. Environ. Manag. 2016, 182, 421-428. [CrossRef]

50. Hussain, A.; Dubey, S.K.; Kumar, V. Kinetic study for aerobic treatment of phenolic wastewater. Water Resour. Ind. 2015, 11, 81-90. [CrossRef]

51. Nascimento, M.S.; Santana, A.L.B.D.; Maranhao, L.S.; Bieber, L.S. Phenolic extractives and natural resistance of wood, biodegradation. In Life of Science; 2013; pp. 349-370. Available online: https://www.intechopen. com/books/biodegradation-life-of-science/phenolic-extractives-and-natural-resistance-of-wood (accessed on 20 March 2020).

52. Latiffi, N.A.A.; Mohamed, R.M.S.R.; Apandi, N.M.; Tajuddin, R.M. Preliminary Assessment of Growth Rates on Different Concentration of Microalgae Scenedesmus sp. in Industrial Meat Food Processing Wastewater. MATEC Web Conf. 2017, 103, 06010. [CrossRef]

53. Singh, P.K.; Shrivastava, A.K. Role of initial cell density of algal bioassay of toxic chemicals. J. Basic Microbial. 2016, 56, 812-819. [CrossRef]

54. Singh, S.P.; Singh, P. Effect of temperature and light on the growth of algae species: A review. Renew. Sustain. Energy Rev. 2015, 50, 431-444. [CrossRef]

55. Barnette, J.; Jeronimidis, G. Wood Quality and Its Biological Basis; John Wiley and Sons: NJ, USA, 2009 ; p. 78. Available online: https://www.wiley.com/en-us/Wood+Quality+and+its+Biological+Basis-p-9781405147811 (accessed on 27 April 2020).

56. Duan, W.; Fanping, M.; Lin, Y.; Wang, G. Toxicological effects of phenol on four marine microalgae. Environ. Toxicol. Pharmacol. 2017, 52, 170-176. [CrossRef] [PubMed]

57. Aniyikaiye, T.E.; Oluseyi, T.; Odiyo, J.O.; Edokpayi, J.N. Physico-chemical analysis of wastewater discharge from selected paint industries in Lagos, Nigeria. Int. J. Environ. Res. Public Health 2019, 16, 1235. [CrossRef] [PubMed]

58. Miazek, K.; Iwanek, W.; Remacle, C.; Richel, A.; Goffin, D. Effect of metals, metalloids and metallic nanoparticles on microalgae growth and industrial product biosynthesis: A Review. Int. J. Mol. Sci. 2015, 16, 23929-23969. [CrossRef]

59. Shariff, A.J.; Lowe, R.W.; Berthiaume, D.; Bryce, J.R.G.; McLean, R.A.N. Unexpected source of phenol in the sulphur-free semichemical pulping of hardwoods. Tappi J. 1989, 72, 177-183.

60. Ghosh, P.; Thakur, I.S.; Kaushi, A. Bioassays for toxicological risk assessment of landfill leachate: A review. Ecotoxicol. Environ. Saf. 2017, 141, 259-270. [CrossRef]

61. Marsalek, J.; Rochfort, Q.; Brownlee, B.; Mayer, T.; Servos, M. An exploratory study of urban runoff toxicity. Water Sci. Technol. 1999, 39, 33-39. [CrossRef] 
62. Žaltauskaitè, J.; Sujetovienè, G.; Čypaitè, A.; Aužbikavičiūtè, A. Lemna minor as a tool for wastewater toxicity assessment and pollutants removal agent. In Proceedings of the 9th International Conference “ENVIRONMENTAL ENGINEERING”, Vilnius, Lithuania, 22-23 May 2014.

63. Šereš, M.; Mocová, K.A.; Moradi, J.; Kriška, M.; Kočí, V.; Hnátková, T. The impact of woodchip-gravel mixture on the efficiency and toxicity of denitrification bioreactors. Sci. Total Environ. 2019, 647, 888-894. [CrossRef]

64. Touria, E.; Douglas, A.C. Manganese toxicity in plants. J. Plant Nutr. 1998, 21, 353-386.

65. Cvjetko, P.; Tolić, S.; Šikić, S.; Balen, B.; Tkalec, M.; Vidaković-Cifrek, Z.; Pavlica, M. Effect of Copper on the Toxicity and Genotoxicity of Cadmium in Duckweed (Lemna minor L.). Arch. Ind. Hyg. Toxicol. 2010, 61, 287-296. [CrossRef] [PubMed]

66. Prasad, S.M.; Dwivedi, R.; Zeeshan, M.; Singh, R. UV-B and cadmium induced changes in pigments, photosynthetic electron transport activity, antioxidant levels and antioxidative enzyme activities of Riccia sp. Acta Physiol. Plant. 2004, 26, 423-430. [CrossRef]

67. Frankart, C.; Eullaffroy, P.; Vernet, G. Photosynthetic responses of Lemna minor exposed to xenobiotics, copper, and their combinations. Ecotoxicol. Environ. Saf. 2002, 53, 439-445. [CrossRef]

68. Kalcíkova, G.; Zupancic, M.; Jemec, A.; Gotvajn, A.Z. The impact of humic acid on chromium phytoextraction by aquaticmacrophyte Lemna minor. Chemosphere 2016, 147, 311-317. [CrossRef]

69. Xiao, Y.; Peijnenburg, W.J.; Chen, G.; Vijyer, M.G. Toxicity of copper nanoparticles to Daphnia magna under different exposure conditions. Sci. Total Environ. 2016, 1, 81-88. [CrossRef]

70. Hoppe, S.; Sundbom, M.; Borg, H.; Breitholtz, M. Predictions of Cu toxicity in three aquatic species using bioavailability tools in four Swedish soft freshwaters. Environ. Sci. Eur. 2015, 27, 25. [CrossRef]

71. Geffard, O.; Gerffard, A.; Chaumot, A.; Vollat, B.; Alvarez, C.; Tusseau-Vuillemin, M.H.; Garric, J. Effects of chronic dietary and waterborne cadmium exposures on the contamination level and reproduction of Daphnia magna. Environ. Toxicol. Chem. 2008, 27, 1128-1134. [CrossRef]

72. Mahassen, M.; El-Deeb, G.; Madlen, M.H.; Eman, Y.M. Effects of pH on Survival, Growth and Reproduction Rates of the Crustacean, Daphnia magna. Aust. J. Basic Appl. Sci. 2011, 5, 1-10.

73. Liber, K.; Solomon, K.R. Acute and Chronic of 2,3,4,6-terachlorophenol and pentachlorophenol to Daphnia and rotifers. Arch. Environ. Contam. Toxicol. 1994, 26, 212-221. [CrossRef] 